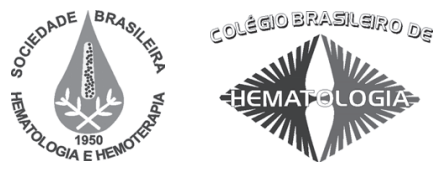

\title{
T-Cell Project: an international, longitudinal, observational study of patients with aggressive peripheral T-cell lymphoma
}

\author{
Projeto de célula-T: Estudo internacional, longitudinal de pacientes com linfoma de célula-T \\ periférica agressivo
}

\author{
Massimo Federico ${ }^{I}$ \\ Monica Bellei ${ }^{1}$ \\ Emanuela Pesce ${ }^{I}$ \\ Emanuele Zucca ${ }^{2}$ \\ Stefano Pileri ${ }^{3}$ \\ Silvia Montoto ${ }^{4}$ \\ Dennis D. Weisenburger ${ }^{5}$ \\ Thomas Ruediger ${ }^{6}$ \\ Y. H. Ko. \\ Raymond Liang ${ }^{8}$ \\ Pier L. Zinzani ${ }^{9}$ \\ Joseph M. Connors ${ }^{10}$ \\ Francine M. Foss ${ }^{11}$ \\ Steven M. Horwitz ${ }^{12}$ \\ Aaron Polliack ${ }^{13}$ \\ Julie M. Vose ${ }^{I 4}$
}

\begin{abstract}
Peripheral T-cell lymphomas (PTCLs) comprise a heterogeneous group of neoplasms that are derived from post-thymic lymphoid cells at different stages of differentiation and with different morphological patterns, phenotypes, and clinical presentations. PTCLs are highly diverse, reflecting the diverse cells from which they can originate and are currently sub-classified using World Health Organization (WHO) 2008 criteria. Peripheral T-Cell Lymphomas account for 5\%-10\% of all lymphoproliferative disorders in the Western hemisphere, with an overall incidence of 0.5-2 per 100,000 individuals per year, and have a striking epidemiological distribution, with higher incidence in Asia. The clinical features of PTCL are extremely heterogeneous. PTCLs express even more clinical diversity than B-cell non-Hodgkin's lymphomas, and there is a close, though not absolute, relationship between some unusual clinical features and certain histological subtypes. Rev. Bras. Hematol. Hemoter. 2009;31(Supl. 2):21-25.
\end{abstract}

Key words: T-cell lymphoma; outcome; chemotherapy; epidemiology.

\section{Introduction}

Despite efforts to transfer the most recent advances in the treatment of other subtypes of B-cell lymphomas to patients with T-cell lymphomas (PTCL), the prognosis of patients with PTCL is still poor and, unfortunately, the optimal therapy for PTCL is still unknown. The complete response rate is rather low, ranging from $40 \%$ to $50 \%$ with a median relapse free survival (RFS) of 2-3 years. As a consequence of the aggressiveness of the disease and of the low efficacy of available salvage treatments, overall survival (OS) is also short and the long-term survival rate is lower than $10 \%$ in many series. Several studies have been performed to assess the contribution of a number of clinical and biological factors

${ }^{1}$ Cattedra di Oncologia II. Dipartimento di Oncologia ed Ematologia Università di Modena e Reggio Emilia, Centro Oncologico Modenese Modena, Italy.

${ }^{2}$ IOSI/ Oncology Institute of Southern Switzerland, IELSG/International Extranodal Lymphoma Study Group, Bellinzona,Switzerland.

${ }^{3}$ Institute of Haematology and Clinical Oncology L. \& A. Seragnoli, University of Bologna, S. Orsola Hospital, Bologna, Italy

${ }^{4}$ Clinical Senior Lecturer, Center for Medical Oncology, St. Bartholomew Hospital, London - England.

${ }^{5}$ Chief, Section of Hematopathology, Department of Pathology and Microbiology, Nebraska Medical Center, Omaha - USA

${ }^{6}$ Pathologisches Institut - Karlsruhe - Germany.

${ }^{7}$ Cell International Project member.

${ }^{8}$ S.H. Ho Chair Professor in Hematology and Oncology, Department of Medicine, University of Hong Kong.

${ }^{9}$ Istituto di Ematologia e Oncologia Medica L. e A. Seragnoli, Policlinico S. Orsola, Bologna, Italy.

${ }^{10}$ Chair, Lymphoma Tumor Group, Chair, Research Ethics Board, BC Cancer Agency, Vancouver, Canada.

${ }^{11}$ Lymphoma Director, Photopheresis \& Experimental Therapeutics (For skin, T and B cell Lymphomas), Tufts University, Yale, USA.

${ }^{12}$ Lymphoma Service, Memorial Sloan-Kettering Cancer Center, New York, NY, USA.

${ }^{13}$ Head of Department of Hematology, Sourasky Medical Center, Tel Aviv, Israel.

${ }^{14}$ Professor of Medicine, Section of Hematology/Oncology, Nebraska Medical Center, Omaha,- USA

Correspondence: Massimo Federico

Cattedra di Oncologia II, Dipartimento di Oncologia ed Ematologia, Università di Modena e Reggio Emilia Centro Oncologico Modenese

Via del Pozzo, 71 - 41100 - Modena, Italy

phone: +39.059.422.2577

E-mail: federico@unimore.it 
Table 1. Mature T-Cell and NK-cell Neoplasms as from WHO $2008^{1}$

\begin{tabular}{ll}
\hline T-cell prolymphocytic leukaemia & $9834 / 3$ \\
T-cell large granular lymphocytic leukaemia & $9831 / 3$ \\
Chronic lymphoproliferative disorder of NK-cells & $9831 / 3$ \\
Aggressive NK cell leukaemia & $9948 / 3$ \\
Systemic EBV positive T-cell lymphoproliferative disease of childhood & $9724 / 3$ \\
Hydroa vaccineforme-like lymphoma & $9725 / 3$ \\
Adult T-cell leukaemia/lymphoma & $9827 / 3$ \\
Extranodal NK/T cell lymphoma, nasal type & $9719 / 3$ \\
Enteropathy-associated T-cell lymphoma & $9717 / 3$ \\
Hepatosplenic T-cell lymphoma & $9716 / 3$ \\
Subcutaneous panniculitis-like T-cell lymphoma & $9708 / 3$ \\
Mycosis fungoides & $9700 / 3$ \\
Sézary syndrome & $9701 / 3$ \\
Primary cutaneous CD30 positive T-cell lymphoproliferative disorders Lymphomatoid papulosis & $9718 / 1$ \\
Primary cutaneous anaplastic large cell lymphoma & $9718 / 3$ \\
Primary cutaneous gamma-delta T-cell lymphoma & $9726 / 3$ \\
Primary cutaneous CD8 positive aggressive epidermotropic cytotoxic T-cell lymphoma & $9709 / 3$ \\
Primary cutaneous CD4 positive small/medium T-cell lymphoma & $9709 / 3$ \\
Peripheral T-cell lymphoma, NOS & $9702 / 3$ \\
Angioimmunoblastic T-cell lymphoma & $9705 / 3$ \\
Anaplastic large cell lymphoma, ALK positive & $9714 / 3$ \\
Anaplastic large cell lymphoma, ALK negative & $9702 / 3$ \\
\hline
\end{tabular}

to the prognosis of PTCL. ${ }^{8,11-17}$ In most of them, adverse prognostic features such as poor performance status, advanced stage, presence of extranodal sites, bulky disease, and high LDH levels were significantly correlated with shorter OS. The usefulness of the International Prognostic Index (IPI), defined for Diffuse Large B-Cell Lymphomas (DLBCLs) has also been investigated and confirmed by several authors.

To better define the clinical outcome of PTCL-not otherwise specified (PTCL-NOS), the Intergruppo Italiano Linfomi (IIL) performed a large study of 385 patients diagnosed and treated in the 1990s and defined a prognostic model specifically devised for patients with this uncommon disease. ${ }^{14}$ Among different clinical parameters assessed at time of diagnosis, age ( $<60$ years), performance status (ECOG PS 2 or higher), LDH level above upper normal range, and bone-marrow involvement were identified as independent predictors in OS. In addition to defining a prognostic model specifically devised for PTCL-NOS, the IIL study underlined the need for cooperation among researchers in order to develop rationally designed and potentially more-efficacious treatment modalities.

More recently, the role of biological features of the disease is emerging as an important issue not only to understand its pathogenesis but also for prognosis and to address specific biological targets altered in the neoplasm. The expression of Th1- or Th2-associated antigens or activated T-cell receptors, for example, has been recently evaluated in a series of T-NHLs. The pattern of expression of such antigens was correlated with the specific subtype of nodal T-cell lymphoma (AITL, ALCL, and PTCL-NOS) and allowed the identification of subgroups of PTCL-NOS patients with different probabilities of survival. ${ }^{18}$ In particular, patients with PTCL-NOS expressing one of Th1 or Th2 antigens tended to show favorable prognoses as compared with cases not expressing Th1 or Th2 antigens.

Significant progress in the prognosis of PTCL can be expected from the novel, sophisticated, and powerful technologies of genomics and proteomics, which will allow more reliable sub-typing of PTCL into distinct clinical groups characterized by different patterns of survival. ${ }^{19-22}$

In 2003 the International T-Cell Lymphoma Project started a broad cooperative study aiming at better defining the clinicopathologic features and prognoses of different neoplastic entities included some in the group of PTCLs and NKTCLs. A cohort of 1,314 cases was collected from 22 centers worldwide, consisting of patients with previously untreated PTCL or NKTCL who were diagnosed between 1990 and 2002. This was the largest series reported to date of peripheral NK/T-cell lymphomas. The results recently published confirm that the clinical outcome for patients with most of these lymphoma subtypes is poor with standard therapies and novel agents and new modalities being needed 
to improve survival. ${ }^{23}$ In the same cohort of patients, analyses of single subsets were also carried out, with the publication, so far, of three additional papers focusing on specific subtypes. Particularly, analyses carried out on ALK negative ALCL suggest that they have to be considered as peculiar entities with clinical and immunophenotypic characteristics that differ in form to those of both ALK-positive ALCL and PTCL-NOS. ${ }^{24}$ In the group of 126 patients diagnosed with aggressive ATLL, the role of the International Prognostic Index in predicting outcome was confirmed. ${ }^{25}$ Finally investigations performed on a subset of 136 patients with extranodal NKTCL show that clinical features and treatment response of extra-nasal NK/T-cell lymphoma are different from those of nasal lymphoma, and that their OS is significantly poorer. ${ }^{26}$

One common limitation of studies on prognosis of PTCL is their retrospective nature. Currently available data are based on analysis performed on a series collected over a long period of time. This aspect is very important as it may introduce relevant biases in the collected series. First, classification systems have changed dramatically over time and cases may have been defined in different ways based on period of diagnosis. Second, some clinical or laboratory data which now are considered of potential prognostic relevance may have not been determined in older series of patients. Third, in a retrospective analysis there is no guarantee that collected series are based on real consecutive cases.

\section{The T- cell project}

Given that all clinical trials and retrospective studies conducted so far underline the difficulty of diagnosing these tumors accurately and stress that currently available therapies are ineffective in many subtypes, in 2006 the International TCell Lymphoma Project thought it would be useful to start a new study based on the prospective registration over a short period of time of patients with peripheral T-cell lymphoma for whom it would be possible to collect an exhaustive set of clinical data and biological information. In fact, the retrospective study allowed the International T-Cell Lymphoma Project to create an international network of collaboration between different Institutions. This network considering the rarity of the disease - is essential to develop and carry out the new clinical studies that are needed in order to improve the clinical and therapeutic approach to PTCLs.

This project, called the "T-Cell Project" opened registration of patients on September 1, 2006, with the aim of collecting a cohort of 1,000 patients diagnosed with Peripheral T-Cell Lymphoma. The T-Cell Project is designed as a prospective collection of information potentially useful to predict the prognosis of newly diagnosed patients with the more frequent subtypes of peripheral T-cell lymphoma (Peripheral T-cell lymphoma not otherwise specified and angioimmunoblastic T-cell lymphoma) and to better define clinical characteristics and outcomes of the more uncommon subtypes.

Patients eligible for the study are those satisfying the following inclusion criteria: previously-untreated patients diagnosed with peripheral T-cell or NK/T-cell lymphoma according to WHO 2001 classification ${ }^{27}$ since September 1, 2006; age over 18; tissue biopsies adequate for diagnosis and classification and available for centralized review; clinical data including baseline information on disease localization and laboratory parameters at staging, features of treatment adopted and assurance of follow-up updating for at least 5 years for living patients. Participating Institutions are asked to provide a consecutive series of cases, without any selection, once permission is obtained from the Institutional Review Board and/or the Scientific Review Committee as required by individual institutional policies. Patients can be included in the project after giving their written informed consent, regardless of their planned treatment (observation only included). Registration is based on locally established histological diagnosis; a panel of expert hematopathologists is planned to review diagnosis of all patients entered in the study. Patient registrations are performed using a dedicated SSL-protected website (www.tcellproject.org) accessible to each investigator by requesting a personal account.

The purpose of the T-Cell Project is to verify whether a prognostic collection of data would result in more accurate information to better define prognosis and to investigate the most adequate treatment strategies for these neoplasms. The main endpoint is 5-year overall survival, the secondary endpoint 5-year event free survival. Additional endpoints are remission rate with initial therapy and 5-year progression free survival.

Due to the fact that prognosis has to be studied in the two most frequent subtypes of PTCLs - PTCL-NOS and AITL - the sample size is calculated based on characteristics of these two subtypes. The T-Cell project aims to accrue 460 patients diagnosed with PTCL-NOS and 460 patients diagnosed with AITL. Since the definition of a sample size for more uncommon PTCLs subtypes is not possible due to their rarity, the study is designed only to prospectively collect all cases of rarer histologies in the same time frame as PTCLNOS and AITL are planned to be accrued. Based on the final accrual of the former retrospective International PTCL study, the success of the F2-study (that prospectively collected 1,093 patients with follicular lymphoma in 2 years 28) and the interest in the project expressed by participants of both of these previous studies, it was originally planned to complete accrual in 2 years.

So far 418 patients have been included in the T-Cell Project. The accrual is a bit under expected due mainly to the lengthiness of procedures needed to achieve authorization by Institutional Review Boards/Ethics Committees of centers willing to take part in the project. Some new institutions have 
Table 2. Histologic type of the 418 patients currently registered in the T-Cell Project

\begin{tabular}{lrc}
\hline Diagnosis & $\mathrm{N}$ & $\%$ \\
\hline PTCL,NOS & 153 & 36,6 \\
Angioimmunoblastic & 66 & 15,8 \\
ALCL, ALK neg & 62 & 14,8 \\
ALCL, ALK pos & 28 & 6,7 \\
Nasal NKTCL & 15 & 3,6 \\
Extranasal NKTCL & 41 & 9,8 \\
Enteropathy-type & 10 & 2,4 \\
Hepatosplenic & 8 & 1,9 \\
Subcutaneous panniculitis like & 8 & 1,9 \\
Peripheral gamma-delta & 4 & 1 \\
Other subtypes (lymphoepiteliod variant, & 23 & 5,4 \\
T-zone variant, Unclassifiable NKTCL) & & \\
\hline Total & 418 & \\
\hline
\end{tabular}

been authorized in the study in the last six months, and some additional ones submitted the request and will soon join in the project. Currently, 13 countries contributed to the accrual. Brazil joined the T-cell Project in February 2009, and so far several patients have been registered. Given this prolonged phase of center activation in the project, the planned accrual will be completed by the end of 2010 (4 years from study opening).

Differently from what was expected, PTCL-NOS account for 153 cases (36.6\%) out of 418 and angioimmunoblastic for only 66 cases $(15.8 \%)$. So the angioimmunoblastic cohort is about half of what was planned. The remaining 199 patients were diagnosed as reported in Table 2.

The T-Cell Project also encourages the collection and the storage at local centers of fresh frozen samples - tumor, serum and mononuclear peripheral cells - for possible further analyses (to be performed at the end of registration period), which are planned to be performed if a consistent number of samples is put together.

Recently, an epidemiologic sub-study has been associated to the T-Cell project. In fact, although a number of case-control studies on non-Hodgkin's lymphoma (NHL) have identified various risk factors for disease, including autoimmune conditions, family history of hematopoietic malignancies, smoking, hepatitis $\mathrm{C}$ infection, and host susceptibility, these risk factors largely pertain to B-cell lymphoma subtypes as they comprise well over $90 \%$ of all NHLs. At present, there are no known epidemiologic risk factors for PTCL or its subtypes. This is largely due to the lack of sample size of PTCL in any one epidemiologic study. So we considered worthy to include an epidemiologic component to the planned prospective enrollment of PTCLs, realizing that its resources would be further enhanced by the addition of standardized information on risk factors for PTCLs.
Indeed, current clinical trials of T-cell lymphomas are not systematically collecting detailed information on patients' family history of cancer, medical and medication history unrelated to the cancer diagnosis and treatment, smoking habits, pesticide exposure, etc. Because many of these factors are significantly associated to risk of NHL, the addition of epidemiologic data to existing clinical and pathologic information would generate unique opportunities to improve our understanding of PTCL etiology and prevention.

\section{Conclusion}

In conclusion, the T-Cell Project highlights the importance of international cooperation, which is imperative when studies are focused on rare diseases such as T-cell lymphomas. Only such efforts will allow new trials to carry out biological investigations to define biological features of each subtype and possibly develop specific and more efficacious therapies for these neoplasms.

\section{Resumo}

Linfomas T periféricos (PTCLs) compreendem um grupo heterogêneo de neoplasias que derivam das células linfoides pós-tímicas nos diversos estágios de maturação, com diversos padrões histológicos, fenotípicos, e clínicos. PTCLs são muito diversos entre si e refletem diversas células das quais foram originadas e são atualmente subclassificadas, usando-se a classificação da Organização Mundial da Saúde (OMS) 2008, apresentada neste texto na tabela 1. PTCLs compreendem 5\%-10\% de todas as doenças linfoproliferativas no mundo ocidental, com uma incidência global de 0.5 a 2 a cada 100.000 pessoas por ano e têm uma distribuição epidemiológica diversa com maior incidencia na Ásia. Os achados clínicos dos PTCLs são muito heterogêneos. PTCLs expressam muito maior variação de apresentações clínicas do que os linfomas $B$, e há uma íntima, mas não absoluta, relação entre algum achado clínico não usual e certos subtipos histológicos. O autor faz aqui uma revisão do assunto altamente contemporâneo Rev. Bras. Hematol. Hemoter. 2009;31(Supl. 2):21-25.

Palavras-chave: Linfomas-T; evolução; quimioterapia; epidemiologia.

\section{References}

1. WHO Classification of Tumours of Haematopoietic and Lymphoid Tissues, Fourth Edition. WHO Classification of Tumours, Volume 2. IARC WHO Classification of Tumours, No 2. (ed 4th edition), World Health Organization, 2008

2. Delves PJ, Roitt IM. The immune system. First of two parts. N Engl J Med. 2000;343(1):37-49.

3. Delves PJ, Roitt IM. The immune system. Second of two parts. N Engl J Med. 2000;343(2):108-17.

4. Jones D, O'Hara C, Kraus MD, Perez-Atayde AR, Shahsafaei A, Wu $\mathrm{L}$, et al. Expression pattern of T-cell-associated chemokine receptors and their chemokines correlates with specific subtypes of T-cell non-Hodgkin lymphoma. Blood. 2000;96(2):685-90. 
5. Picker LJ, Weiss LM, Medeiros LJ, Wood GS, Warnke RA Immunophenotypic criteria for the diagnosis of non-Hodgkin's lymphoma. Am J Pathol 128:181-201, 1987

6. Cooke CB, Krenacs L, Stetler-Stevenson M, Greiner TC, Raffeld M, Kingma DW, et al. Hepatosplenic T-cell lymphoma: a distinct clinicopathologic entity of cytotoxic gamma delta T-cell origin Blood. 1996;88(11):4265-74

7. Melnyk A, Rodriguez A, Pugh WC, Cabannillas F. Evaluation of the Revised European-American Lymphoma classification confirms the clinical relevance of immunophenotype in 560 cases of aggressive non-Hodgkin's lymphoma. Blood. 1997;89(12):4514-20.

8. Rüdiger T, Weisenburger DD, Anderson JR, Armitage JO, Diebold J, MacLennan KA, et al. Peripheral T-cell lymphoma (excluding anaplastic large-cell lymphoma): results from the NonHodgkin's Lymphoma Classification Project. Ann Oncol. 2002; 13(1):140-9.

9. Delmer A, Zittoun R. Other peripheral T-cell Lymphomas, Non Hodgkin's Lymphomas, 1994, pp 927-955

10. Armitage JO, Weisenburger DD. New approach to classifying nonHodgkin's lymphomas: clinical features of the major histologic subtypes. Non-Hodgkin's Lymphoma Classification Project. J Clin Oncol. 1998;16(8):2780-95.

11. Ascani S, Zinzani PL, Gherlinzoni F, Sabattini E, Briskomatis A, de Vivo A, et al. Peripheral T-cell lymphomas. Clinico-pathologic study of 168 cases diagnosed according to the R.E.A.L. Classification. Ann Oncol. 1997;8(6):583-92.

12. López-Guillermo A, Cid J, Salar A, López A, Montalbán C, Castrillo JM, et al. Peripheral T-cell lymphomas: initial features, natural history, and prognostic factors in a series of 174 patients diagnosed according to the R.E.A.L. Classification. nn Oncol. 1998; 9(8):849-55.

13. Savage KJ, Chhanabhai M, Gascoyne RD, Connors JM. Characterization of peripheral T-cell lymphomas in a single North American institution by the WHO classification. Ann Oncol. 2004;15(10):1467-75.

14. Gallamini A, Stelitano C, Calvi R, Bellei M, Mattei D, Vitolo U, et al. Peripheral T-cell lymphoma unspecified (PTCL-U): a new prognostic model from a retrospective multicentric clinical study. Blood. 2004;103(7):2474-9.

15. Zaja F, Russo D, Silvestri F, Fanin R, Damiani D, Infanti L, et al. Retrospective analysis of 23 cases with peripheral T-cell lymphoma, unspecified: clinical characteristics and outcome. Haematologica. 1997;82(2):171-7.

16. Ansell SM, Habermann TM, Kurtin PJ, Witzig TE, Chen MG, Li $\mathrm{CY}$, et al. Predictive capacity of the International Prognostic Factor Index in patients with peripheral T-cell lymphoma. J Clin Oncol. 1997;15(6):2296-301.

17. Rodriguez-Abreu D, Filho VB, Zucca E. Peripheral T-cell lymphomas, unspecified (or not otherwise specified): a review. Hematol Oncol. 2008;26(1):8-20.

18. Tsuchiya T, Ohshima K, Karube K, Yamaguchi T, Suefuji H, Hamasaki M, et al. Th1, Th2, and activated T-cell marker and clinical prognosis in peripheral T-cell lymphoma, unspecified: comparison with AILD, ALCL, lymphoblastic lymphoma, and ATLL. Blood. 2004;103(1):236-41.

19. Piccaluga PP, Agostinelli C, Califano A, Rossi M, Basso K, Zupo S, et al. Gene expression analysis of peripheral $\mathrm{T}$ cell lymphoma unspecified, reveals distinct profiles and new potential therapeutic targets. J Clin Invest. 2007;117(3):823-34.

20. de Leval L, Rickman DS, Thielen C, Reynies A, Huang YL, Delsol $\mathrm{G}$, et al. The gene expression profile of nodal peripheral T-cell lymphoma demonstrates a molecular link between angioimmunoblastic T-cell lymphoma (AITL) and follicular helper T (TFH) cells. Blood. 2007;109(11):4952-63.
21. Lamant L, de Reyniès A, Duplantier MM, Rickman DS, Sabourdy $\mathrm{F}$, Giuriato $\mathrm{S}$, et al. Gene-expression profiling of systemic anaplastic large-cell lymphoma reveals differences based on ALK status and two distinct morphologic ALK+ subtypes. Blood. 2007;109 (5):2156-64

22. Salaverria I, Beà $\mathrm{S}$, Lopez-Guillermo $\mathrm{A}$, Lespinet $\mathrm{V}$, Pinyol $\mathrm{M}$, Burkhardt B, et al. Genomic profiling reveals different genetic aberrations in systemic ALK-positive and ALK-negative anaplastic large cell lymphomas. Br J Haematol. 2008;140(5):516-26.

23. Vose J, Armitage J, Weisenburger D; International T-Cell Lymphoma Project. International peripheral T-cell and natural killer/T-cell lymphoma study: pathology findings and clinical outcomes. J Clin Oncol. 2008;26(25):4124-30.

24. Savage KJ, Harris NL, Vose JM, Ullrich F, Jaffe ES, Connors JM, et al. ALK- anaplastic large-cell lymphoma is clinically and immunophenotypically different from both ALK+ ALCL and peripheral T-cell lymphoma, not otherwise specified: report from the International Peripheral T-Cell Lymphoma Project. Blood. 2008;111(12):5496-504.

25. Suzumiya J, Ohshima K, Tamura K, Karube K, Uike N, Tobinai K, et al. The International Prognostic Index predicts outcome in aggressive adult T-cell leukemia/lymphoma: analysis of 126 patients from the International Peripheral T-Cell Lymphoma Project. Ann Oncol. 2009;20(4):715-21.

26. Au WY, Weisenburger DD, Intragumtornchai T, Nakamura S, Kim WS, Sng I, et al. Clinical differences between nasal and extranasal natural killer/T-cell lymphoma: a study of 136 cases from the International Peripheral T-Cell Lymphoma Project. Blood. 2009;113(17):3931-7.

27. Tumours of Haematopoietic and Lymphoid Tissues - Pathology and Genetics, World Health Organization of Tumours. Lyon, IARC Press, 2001

28. Federico M, Bellei M, Marcheselli L, et al. Follicular Lymphoma International Prognostic Index 2: A new prognostic index for follicular lymphoma developed by the International Follicular Lymphoma Prognostic Factor Project. J. Clin. Oncol., in press

O tema apresentado foi proposto pela Organização do $8^{\circ}$ Simpósio da Associação Ítalo-Brasileira de Hematologia, realizado durante o XIII Congresso de Transplante de Medula Óssea.

Publicado após concordância do editor.

Conflito de interesse: sem conflito de interesse

Recebido: 07/07/2009

Aceito: 16/07/2009 